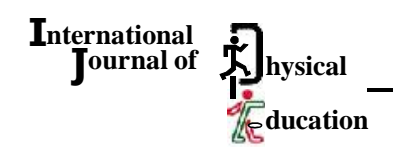

DOI : 10.15740/HAS/IJPE/7.2/50-54

e ISSN-0976-7924 | Visit us - www.researchjournal.co.in

Research Paper

Volume 7 | Issue 2 | October, 2014 | 50-54

\title{
Food habits, nutritional profile and physical fitness of physical education students
}

\section{U. ROOPA AND B. KASTURIBA ${ }^{1}$}

Received : 04.04.2014; Revised : 03.09.2014; Accepted : 17.09.2014

Members of the Research Forum :

Associated Authors:

'Department of Food Science and

Nutrition,University of Agricultural

Sciences, DHARWAD (KARNATAKA) INDIA

Author for correspondence U. ROOPA

Department of Food Science and Nutrition,University of Agricultural Sciences, DHARWAD (KARNATAKA) INDIA

Email: roopsu.08@gmail.com

\section{- ABSTRACT}

The nutritional status of sports persons plays an important role in attaining a high level of achievement in sports. Poor sports performance could be partly due to poor physique and unsatisfactory physical fitness resulting from undernourishment. The present study documented the food habits, nutritional profile and physical fitness of thirty male sports persons (21-23 years) studying in a physical education college in Dharwad city. The subjects consumed some special foods regularly, which they thought would help to improve health and performance in sports. Idli was the most preferred pre-event food followed by fruits and biscuits. Glucose was consumed by majority of the sports persons during the event. Whereas, glucose and biscuits were the widely consumed post-event foods. Heavy meal, fried and spicy foods were avoided before the event. The mean height and weight of the subjects were $173.53 \mathrm{~cm}$ and 65.31 $\mathrm{kg}$, respectively. While, the mean body fat and hemoglobin contents were 19.25 per cent and $12.41 \mathrm{~g} / \mathrm{dl}$, respectively. The mean consumption of all the foods was lower than the suggested dietary allowance except for pulses. The intake of nutrients was far less than the recommendations among the subjects indicating nutritional deficiency.

- Key Words : Nutritional status, Sports persons, Nutrient intake, Anthropometry

- How to cite this paper : Roopa, U. and Kasturiba, A. (2014). Food habits, nutritional profile and physical fitness of physical education students. Internat. J. Phy. Edu., 7 (2) : 50-54. 